\title{
Engineered nanoparticles interacting with cells: size matters
}

\author{
Li Shang ${ }^{1}$, Karin Nienhaus ${ }^{1}$ and Gerd Ulrich Nienhaus ${ }^{1,2,3^{*}}$
}

\begin{abstract}
With the rapid advancement of nanoscience and nanotechnology, detailed knowledge of interactions between engineered nanomaterials and cells, tissues and organisms has become increasingly important, especially in regard to possible hazards to human health. This review intends to give an overview of current research on nano-bio interactions, with a focus on the effects of NP size on their interactions with live cells. We summarize common techniques to characterize NP size, highlight recent work on the impact of NP size on active and passive cellular internalization and intracellular localization. Cytotoxic effects are also discussed.
\end{abstract}

Keywords: Nanoparticle, Cellular uptake, Protein corona, Endocytosis, Red blood cell, Cytotoxicity

\section{Introduction}

In recent years, nanoparticles (NPs) and other nanomaterials have entered essentially all areas of our everyday lives. In industrial applications, they have become indispensable components of catalysts [1], sensors [2] or photovoltaic devices [3]. In the biomedical field, they have found wide-spread use as nanovaccines [4], nanodrugs [5] and diagnostic imaging tools [6]. However, our knowledge about biological effects and, importantly, potential risks of the omnipresent (intended and unintended) exposure to nanomaterials has not kept up with the pace of these developments and is still very limited $[7,8]$.

NPs may invade the human body via inhalation, ingestion or through the skin (Figure 1). Once they have entered a biological milieu, NPs will inevitably come into contact with a huge variety of biomolecules including proteins, sugars and lipids that are dissolved in body fluids, such as the interstitial fluid between cells, lymph or blood. These biomolecules immediately coat the NP surfaces and form the so-called 'protein corona' [9-11], which determines the biological identity of the NP [12]. Its composition is dynamic

\footnotetext{
* Correspondence: uli.nienhaus@kit.edu

${ }^{1}$ Institute of Applied Physics and Center for Functional Nanostructures (CFN), Karlsruhe Institute of Technology (KIT), Wolfgang-Gaede-Strasse 1, 76131 Karlsruhe, Germany

${ }^{2}$ Institute of Toxicology and Genetics (ITG), Karlsruhe Institute of Technology (KIT), Hermann-von-Helmholtz-Platz 1, 76344 Eggenstein-Leopoldshafen, Germany

Full list of author information is available at the end of the article
}

and depends on the relative concentrations of the individual components and on their affinities toward the NP surface. In fact, NPs have to be viewed as evolving systems that adapt to varying concentrations of the biomolecules present in the fluid. It has been suggested that the 'final corona' reflects its own prior history [13].

NPs have to surmount the cell membrane to intrude cells. One of the hallmarks of any cell membrane is its ability to selectively control the flow of ions and molecules into and out of the cell, and to maintain a separation between the cytosol and the extracellular environment. Large macromolecular agglomerates, e.g., protein assemblies, lipoprotein particles, viruses and also NPs are typically encapsulated in vesicles and selectively transported into and out of the cells via endocytosis and exocytosis, respectively (Figure 1). Different types of endocytosis mechanisms are known, varying with the size of the transport vesicle, cargo properties and the internalization machinery involved. In most cells, internalization occurs via pinocytosis. In this process, an invagination forms in the cell membrane that is finally pinched off so as to generate a vesicle in the cytoplasm that contains the internalized materials. Typically, the inward budding vesicles contain receptor proteins that recognize specific chemical groups on the molecules to be internalized. Thus, if proteins adsorbed to an NP trigger cell surface receptors, they will readily activate the cell's uptake machinery, whereas adsorbed proteins that only weakly interact with membrane-associated biomolecules will reduce the uptake of the 'disguised' NPs. Specialized cells, so- 


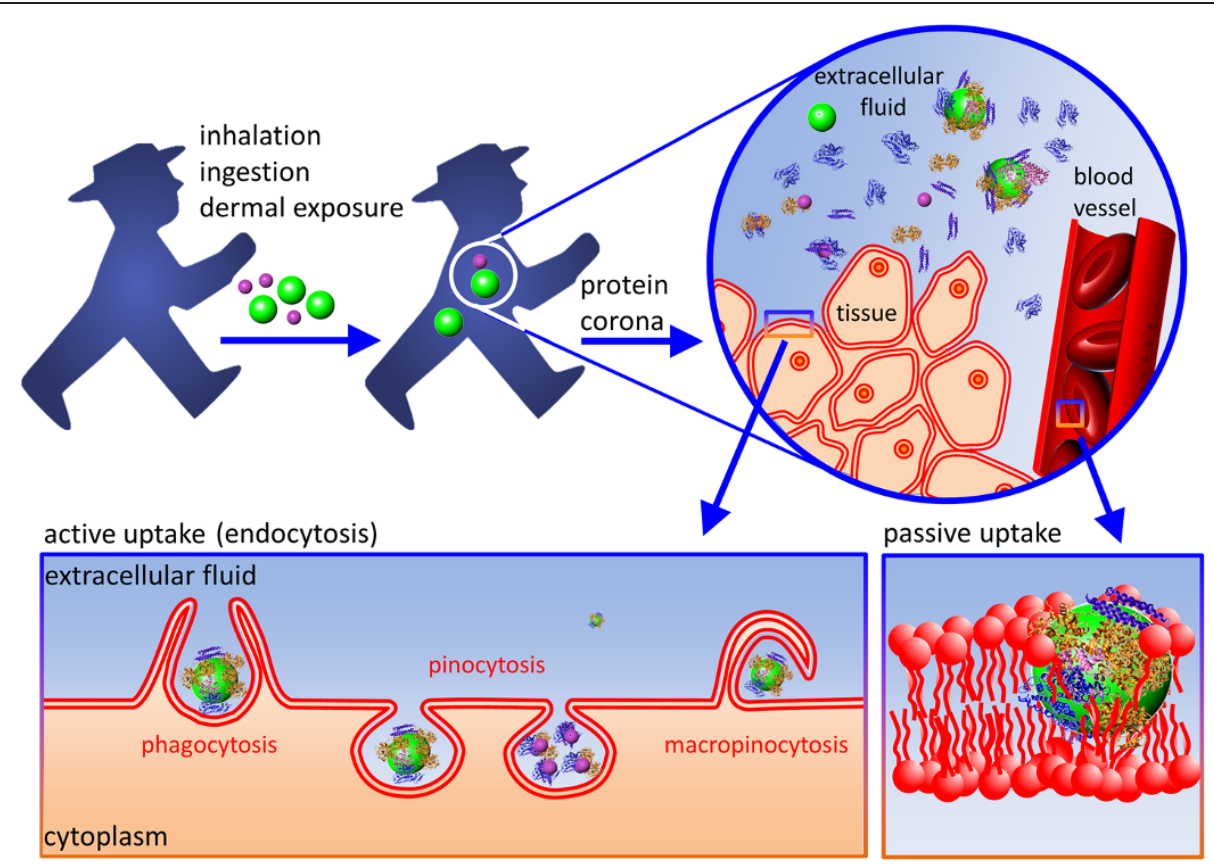

Figure 1 Nanoparticle uptake. NPs may enter the human body via inhalation, ingestion or through the skin. In the extracellular fluid, NPs are coated by proteins and other biomolecules. The so-called protein corona determines how the NP interacts with a cell. Cellular internalization may involve active (receptor-mediated) or passive transport across the cell membrane.

called 'professional phagocytes', such as macrophages, neutrophils, and monocytes are capable of phagocytosis, a form of endocytosis in which the cell engulfs larger particles. In addition to intruding cells by active transport, NPs may also enter cells by passive penetration of the cell membrane. In fact, for cells lacking the endocytosis machinery such as red blood cells (RBCs), passive transport is the only option.

Regardless of the specific internalization mechanism, the cell-NP interactions are, on the one hand, modulated by physicochemical properties of the NPs including size, shape, surface charge and surface chemistry [14] and, on the other hand, by cell-specific parameters such as cell type or cell cycle phase [15]. The uptake efficiency might even be affected by specific properties of the experimental setup [16]. A quantitative understanding of the NPbiomolecule/membrane interaction is, therefore, an important prerequisite for designing and engineering NPs with intentionally enhanced or suppressed cellular uptake $[17,18]$. In the present review, we shall focus mainly on the effect of NP size on the interaction with live cells. We present a survey of methods to determine the size of NPs, investigate the impact of the NP size on active and passive uptake and discuss their cytotoxic effects.

\section{Characterization of the NP size in biological media}

To correlate a particular physicochemical property of a NP with biological responses and to ensure that these results are reproducible and meaningful, an accurate characterization of the NP is essential. NP size is a key parameter (in the following, particle size always refers to the diameter). Many NPs are composed of a 'heavy' core (e.g., a metal or semiconductor nanocrystal) surrounded by small organic ligands to ensure colloidal stability. Electron microscopy techniques such as transmission electron microscopy (TEM) can easily provide accurate size measurements with sub-nanometer resolution. However, organic surface ligands are difficult to resolve owing to their low electron density, so the TEMdetermined size mainly reflects the size of the core. In addition, the requirement of high vacuum for TEM imaging calls for complicated sample preparation procedures that can result in NP aggregation [19]. Dynamic light scattering (DLS) is a widely used technique for NP size determination in suspension. DLS is based on scattering intensity fluctuations due to Brownian motion of NPs in suspension and relates the diffusion coefficient to the size via the Stokes-Einstein equation. The measured hydrodynamic diameter reflects the dimension of the NP (core plus shell) together with layer of surface-bound solvent. DLS provides a simple and speedy measurement of NP size in biological media. However, the method suffers from low sensitivity toward small particles and possible interference from light-absorbing species [20]. Fluorescence correlation spectroscopy (FCS) is a sensitive technique capable of measuring the hydrodynamic diameter of freely diffusing NPs, if these are either intrinsically fluorescent or have been labeled with fluorescent dyes [9]. The FCS method is based on the analysis 
of the duration of brief bursts of photons from individual NPs passing through a tiny focal volume of typically $1 \mathrm{fL}\left(10^{-15} \mathrm{l}\right)$, from which the NP size can be calculated via autocorrelation analysis [21,22]. As with DLS, the size information comprises both the core and the ligand layer. Other techniques to determine NP size include nanoparticle tracking analysis (NTA) [23], atomic force microscopy (AFM) [24], absorption spectroscopy [25] and analytical ultracentrifugation [26]. Advantages as well as limitations of the different techniques are summarized in Table 1.

One should be aware that NP preparations are often polydisperse. The DLS technique directly provides the size distribution information. Still, one has to be careful when interpreting the data because DLS is based on density-density correlations and, therefore, the intensity scales with the sixth power of the NP diameter. Caution is advised when dealing with samples containing particles of markedly different sizes. Size distributions may also be quantified by using AFM. Such data have been proposed to be more accurate than those obtained via DLS [27]. TEM image analysis suffers from limited sampling, so that the selected NPs may not be representative of the whole sample. Overall, it is advisable to apply different methods to ensure a robust size determination.

Independent of the technique chosen for size characterization, the NPs should - if at all possible - be suspended in the medium/solvent that will be used to expose the NPs to the biological samples during such measurements. The colloidal stability of NP suspensions is influenced by many factors including the solution ionic strength, $\mathrm{pH}$ and solvent composition. Because NPs are often charge-stabilized, the colloidal stability of NPs in pure water is significantly different from that in biologically relevant media $[28,29]$. Particularly, one has to be aware that biomolecules present in biological media, such as proteins, will inevitably adsorb on the NP surface [30-32], which leads to an increase in the hydrodynamic radius of the NP. In fact, the NP size may even influence the characteristics of the protein corona [33-36], such as thickness, composition and protein activity, which may modulate their cellular interactions.

\section{NP size effects on active cellular internalization}

Endocytosis is a fundamental biological process used by cells to internalize (bio)molecules and, because of their similar size, also NPs $[37,38]$. It may involve the engagement of either clathrin or caveolin pits, but may also be independent of these proteins. As is apparent from the studies listed in Table 2, NP size may affect the uptake efficiency and kinetics, the internalization mechanism and also the subcellular distribution. A size-dependent uptake in different cell lines has been observed for $\mathrm{Au}$ [29,39,40], mesoporous silica [41], polystyrene [42] and iron oxide NPs [43], with the maximum cellular uptake at a NP core size in the range of $30-50 \mathrm{~nm}$, which suggests that there is an optimal size for active uptake.

Hökstra et al. [59] used a range of fluorescent latex beads of defined sizes $(50-1,000 \mathrm{~nm})$ to investigate the effect of NP size on the entry pathway in nonphagocytic B16 cells. Internalization of NPs $<200 \mathrm{~nm}$ was observed to involve clathrin-coated pits. With increasing size, a shift towards caveolae-mediated internalization became apparent, which turned out to be the predominant entry route for $500-\mathrm{nm}$ particles. Rafailovich et al. [50] reported that 45-nm Au NPs penetrated cells via clathrin-mediated endocytosis, while the smaller 13-nm NPs entered mostly via phagocytosis.

By using spinning disk confocal microscopy and quantitative image analysis, Nienhaus and coworkers have systematically investigated the uptake of various NPs in the range of $3.3-100 \mathrm{~nm}$ by live HeLa cells. Interestingly, QDs [60] and $\mathrm{Au}$ nanoclusters (AuNCs) [61,62] with less than $10 \mathrm{~nm}$ diameter were found to accumulate on the plasma membrane before gradually entering the intracellular region (Figure 2). In stark contrast, large polystyrene NPs $(100 \mathrm{~nm})$ were directly internalized without detectable prior accumulation at the plasma

Table 1 Commonly used experimental techniques to characterize NP size

\begin{tabular}{|c|c|c|}
\hline Technique & Advantages & Limitations \\
\hline TEM & Direct visualization, high resolution & $\begin{array}{l}\text { NP aggregation during sample preparation, electron beam damage, } \\
\text { preference for electron-dense atomic species }\end{array}$ \\
\hline DLS & Size distribution information available, fast, simple & Signal dominated by larger NPs, interference from luminescent species \\
\hline NTA & Real time analysis, particle-by-particle measurement & Suitable to a certain size range, interference from luminescent species \\
\hline FCS & $\begin{array}{l}\text { High sensitivity, small sample volume, particle-by- } \\
\text { particle measurement }\end{array}$ & NPs need to be luminescent, sensitive to aggregates \\
\hline AFM & High size resolution, 3-D profile & Slow speed, limited scanning area \\
\hline Absorption spectra & Simple, fast & Applicable to plasmonic (Au, Ag) and semiconductor (CdSe, CdTe) NPs \\
\hline $\begin{array}{l}\text { Analytical } \\
\text { ultracentrifugation }\end{array}$ & $\begin{array}{l}\text { Size distribution information available, high size } \\
\text { resolution }\end{array}$ & Density of NPs needs to be known, long measurement time \\
\hline
\end{tabular}

Abbreviations used: TEM transmission electron microscopy, DLS dynamic light scattering, NTA nanoparticle tracking analysis, FCS fluorescence correlation spectroscopy, AFM atomic force microscopy. 
Table 2 Size dependence of active cellular NP uptake

\begin{tabular}{|c|c|c|c|c|c|}
\hline NPs & Size (nm Ø) & Cell lines & Techniques & Main conclusions & Ref. \\
\hline $\mathrm{Au}$ & $2-15$ & MCF-7 & ICP-MS, TEM & $\begin{array}{l}\text { Higher uptake of smaller NPs; } 2 / 6 \mathrm{~nm} \text { locate in cytoplasm and } \\
\text { nucleus, } 15 \mathrm{~nm} \text { only in cytoplasm }\end{array}$ & {$[44]$} \\
\hline QDs & $2-7$ & A-427 & FCS & Size-dependent internalization efficiency & {$[45]$} \\
\hline $\mathrm{Au}$ & $2.4-89$ & $\cos 1$ & Silver staining, CLSM & $\begin{array}{l}2.4 \mathrm{~nm} \text { : in nucleus; } 5.5 \text { and } 8.2 \mathrm{~nm} \text { : partially in cytoplasm; } 16 \mathrm{~nm} \\
\text { and above: no uptake }\end{array}$ & [46] \\
\hline $\mathrm{Au}$ & $2-100$ & SK-BR-3 & CLSM & 40/50 nm: greatest effect & [47] \\
\hline $\mathrm{Au}$ & $4-17$ & HeLa & AFM & Uptake increases with NP size & [48] \\
\hline $\mathrm{TiO}_{2}$ & $5-80$ & A549 & $\begin{array}{l}\text { Light scattering } \mu \text { - } \\
\text { Raman, TEM }\end{array}$ & Uptake depends on overall size (with hard corona) & [49] \\
\hline $\begin{array}{l}\text { Iron } \\
\text { oxide }\end{array}$ & $8-65$ & RAW264.7 & ICP-AES & 37 nm (HD 100 nm): highest uptake & [43] \\
\hline $\mathrm{Au}$ & $10-50$ & NRK & TEM, ICP-MS & Uptake efficiency: $50>25>10 \mathrm{~nm}$ & [44] \\
\hline $\mathrm{Au}$ & 13,45 & CF-31 & TEM, SEM, CLSM & $\begin{array}{l}45 \mathrm{~nm} \text { : clathrin-mediated endocytosis, } 13 \mathrm{~nm} \text { : mostly } \\
\text { phagocytosis }\end{array}$ & {$[50]$} \\
\hline $\mathrm{Au}$ & $14-100$ & HeLa & ICP-AES, TEM & $50 \mathrm{~nm}$ : maximum uptake & [39] \\
\hline $\mathrm{Au}$ & $15-55$ & SK-BR-3 & SEM, ICP-MS, & Surface ligands affect size dependency & [51] \\
\hline $\mathrm{Au}$ & $15-90$ & J774A.1 & ICP-AES & No significant size dependency & [52] \\
\hline $\mathrm{Au}$ & $16-58$ & RAW 264.7, HepG2 & ICP-MS, TEM & $\begin{array}{l}\text { Negatively charged: } 40 \mathrm{~nm} \text { highest uptake; positively charged: } \\
\text { no size-dependent uptake }\end{array}$ & [53] \\
\hline $\mathrm{Au}$ & $20-80$ & CHO-K1, HeLa, MCF-7 & $\begin{array}{l}\text { Flow cytometry, } \\
\text { ICP-AES, TEM, }\end{array}$ & Less internalization with increasing size & [54] \\
\hline PS & $20-100$ & 1321 N1, A549 & $\begin{array}{l}\text { CLSM, flow } \\
\text { cytometry }\end{array}$ & $40 \mathrm{~nm}$ : fastest internalization rate & [42] \\
\hline MSN & $30-280$ & HeLa & CLSM, ICP-MS & $50 \mathrm{~nm}$ : maximum uptake & [41] \\
\hline $\mathrm{Au}$ & $30-90$ & PC3 & TEM, ICP-MS & $50 \mathrm{~nm}$ : maximum uptake & [29] \\
\hline $\mathrm{SiO}_{2}$ & 32,83 & Caco-2 & CLSM & $32 \mathrm{~nm}$ : enter nucleus, migrate faster & [55] \\
\hline PS & $40-2000$ & $\begin{array}{l}\text { HeLa, A549, } 1321 \text { N1, HCMEC } \\
\text { D3, RAW } 264.7\end{array}$ & $\begin{array}{l}\text { CLSM, flow } \\
\text { cytometry }\end{array}$ & $\begin{array}{l}\text { Uptake highly size-dependent for all cell lines, larger NPs enter } \\
\text { more slowly }\end{array}$ & [56] \\
\hline $\mathrm{Au}$ & $45-110$ & CL1-0, HeLa & Scattering imaging & $45 \mathrm{~nm}$ : maximum uptake & [40] \\
\hline polymer & $50-300$ & Caco-2, HT-29 & $\begin{array}{l}\text { Deserno's model, } \\
\text { CLSM }\end{array}$ & 100 nm: maximum uptake & [57] \\
\hline polymer & $150-500$ & L02, SMMC-7221 & Fluorimetry & Large NPs with high net charge: uptake more efficient & [58] \\
\hline
\end{tabular}

Abbreviations used: ICP-MS inductively coupled plasma mass spectrometry, CLSM confocal laser scanning microscopy, ICP-AES inductively coupled plasma atomic emission spectrometry, SEM scanning electron microscopy, MSN mesoporous silica nanoparticles.

membrane (Figure 2) [63,64]. Lunov et al. [65] demonstrated that, despite having the same size, 100 -nm carboxy (PS-COOH) and amino functionalized polystyrene $\left(\mathrm{PS}-\mathrm{NH}_{2}\right) \mathrm{NPs}$ were internalized by human macrophages and by undifferentiated and PMA-differentiated monocytic THP-1 cells via different mechanisms. Notably, the mechanism did not only depend on the NP type and the cell type, but also on the experimental conditions (buffer or medium supplemented with human serum). They also noticed that only the PS- $\mathrm{NH}_{2}$ NPs triggered NLRP3 inflammasome activation and subsequent release of proinflammatory interleukin $1 \beta$ (IL-1 $\beta$ ) by human macrophages [66]. Hühn et al. [67] modified colloidal AuNPs with amphiphilic polymers to obtain NPs with identical physical properties except for the sign of the charge (negative/positive) and showed that the uptake rate by cells was higher for positively than for negatively charged NPs.

The size-dependent interaction of NPs with the cell membrane is likely related to the membrane-wrapping process that initiates receptor-mediated endocytosis. It requires the concerted formation of multiple NPreceptor interactions [68,69]. Small NPs have less ligand-to-receptor interactions than larger ones; thus, several small NPs need to interact simultaneously with receptors in close proximity to trigger membrane wrapping. In contrast, an individual, large NP can act as a cross-linking agent to cluster receptors and induce uptake. Mathematical modeling has demonstrated that receptor-mediated endocytosis is optimal when there is 

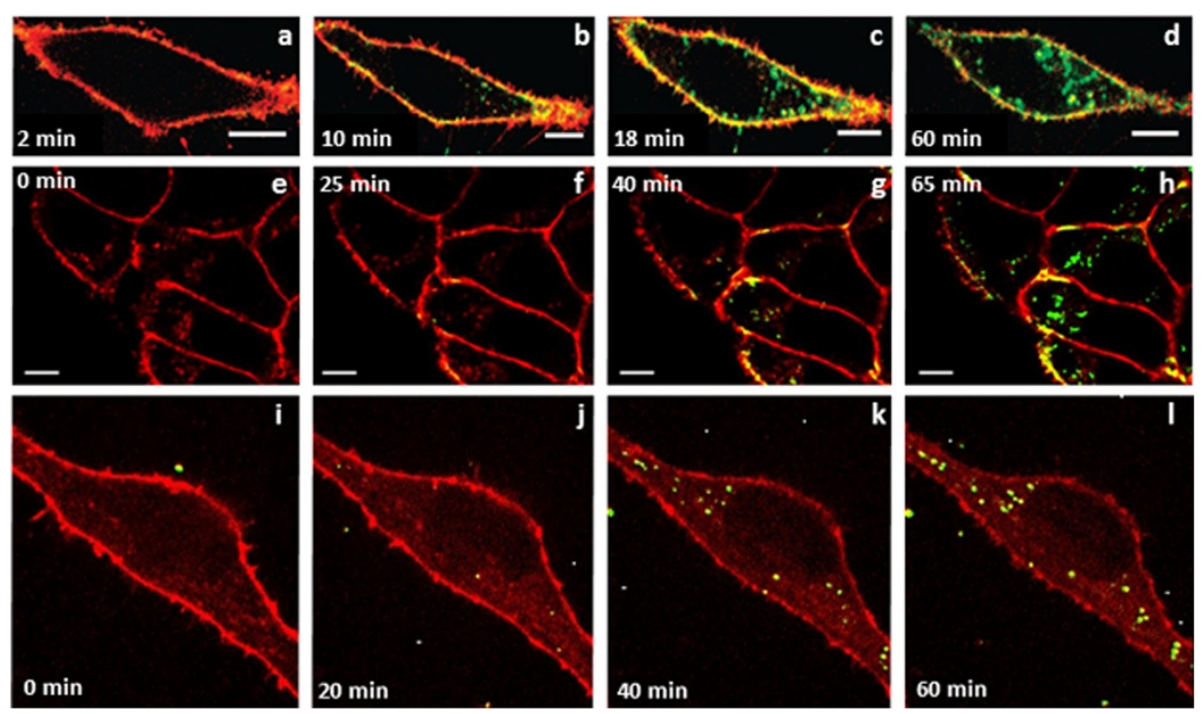

Figure 2 Active NP uptake. $(\mathbf{a}-\mathbf{d})$ Internalization of DPA-QDs $(8 \mathrm{~nm})$ by HeLa cells [60]. (e - $\mathbf{h})$ Uptake of DHLA-AuNCs (3.3 nm) by HeLa cells [61]. (i - I) Uptake of polystyrene NPs (100 nm, coated with carboxylic groups) by mesenchymal stem cells (MSCs) [63]. Reproduced with permission from the American Chemical Society and the Royal Chemical Society.

no ligand shortage on the NP and no localized receptor shortage on the cell surface [70]. Thermodynamically, a $50-60 \mathrm{~nm}$ NP is capable of recruiting enough receptors to successfully trigger internalization. The nature of the protein corona, which is controlled by the NP surface ligands, may also affect the membrane response and, thereby, modify the cellular responses toward the NPs [52,71]. Considering that most uptake studies involving live cells have been performed in cell culture media supplemented with protein mixtures in varying compositions, it is not surprising that apparently 'identical' studies in some cases yielded conflicting results.

The size - as well the coating - can also influence the subcellular distribution of the internalized NPs. Lovric et al. [72] demonstrated that positively charged 5.2-nm CdTe QDs were distributed throughout the cytoplasm of N9 cells but did not enter the nucleus, whereas positively charged 2.2-nm QDs were localized predominantly in the nuclear compartment. In contrast, Parak et al. [73] found that the size of the silica-coated QDs (8 and $16 \mathrm{~nm}$, functionalized with thiols, amines or mercaptopropionic acid) did not influence the intracellular distribution. Oh et al. [46] investigated the cellular uptake of AuNPs coated with a cell-penetrating peptide. They reported that the ultimate intracellular destination was governed by the AuNP diameter. While the smallest, 2.4-nm AuNPs were found to localize to the nucleus, intermediate, 5.5 - and 8.2-nm particles remained sequestered within the endolysosomal system. The 16-nm and larger AuNPs did not enter the cells on the experimental time scale, which is at variance with other reports (see Table 2).
These few examples already show the wide range of conclusions that can be drawn from NP uptake data. A dependence on one particular physicochemical parameter, e.g., the core material of a core-shell NP, can be measured only if all other parameters are kept constant. There are only a few studies so far where this rule was strictly obeyed.

\section{NP size effects on passive uptake}

Red blood cells (RBCs) lack a cell nucleus, most organelles and, most importantly, the endocytic machinery [74]. Therefore, they have become valuable as a model system to investigate passive NP uptake. In 2005, Geiser et al. [75] analyzed the uptake of PS-NPs by RBCs and found that $<200$ $\mathrm{nm}$ but not $1-\mu \mathrm{m}$ NPs enter RBCs. Rothen-Rutishauser and coworkers [76] refined the study and exposed RBCs to NPs of different material, size and surface charge (Table 3), and visualized them inside RBCs using confocal laser scanning microscopy (CLSM) in combination with digital data restoration, conventional TEM, and energy filtering TEM. A quantitative analysis revealed that only the size determined the uptake efficiency. They confirmed that particles $<200 \mathrm{~nm}$ enter RBCs. The overall numbers were extremely small, however, with less than 1 particle per cell on average.

Zhao et al. [79] investigated the interactions of mesoporous silica nanoparticles (MSNs) having different sizes and surface properties with RBC membranes using membrane filtration, flow cytometry, and various microscopic techniques to evaluate their potential for intravenous drug delivery. The study focused on the first step of NP uptake, i.e., the interaction of the NPs with the cell membrane. Small MCM-41-type MSNs ( 100 nm) 
Table 3 Size dependence of passive cellular NP uptake

\begin{tabular}{|c|c|c|c|c|c|}
\hline NPs & Size $(\mathrm{nm} \emptyset)$ & Bio-system & Techniques & Main conclusions & Ref \\
\hline $\begin{array}{l}\text { DPA- } \\
\text { QDs }\end{array}$ & 8 & RBCs & CLSM, SEIRAS & QDs penetrate cell membranes without pore formation & [77] \\
\hline MSNs & $100-300$ & $\mathrm{RBCs}$ & TEM & $\begin{array}{l}\text { Hemolytic properties of MSNs related to silanol groups accessible to the cell } \\
\text { membranes }\end{array}$ & [78] \\
\hline MSNs & $100-600$ & $\mathrm{RBCS}$ & CLSM, TEM & Strongly dependent on surface chemistry and NP size & {$[79]$} \\
\hline PS & $78-2,000$ & $\mathrm{RBCS}$ & CLSM & NPs $<0.2 \mu \mathrm{m}$ enter RBCs & [75] \\
\hline PS & $2-1,000$ & \multirow[t]{3}{*}{$\mathrm{RBCs}$} & \multirow[t]{3}{*}{ CLSM, TEM } & \multirow{3}{*}{$\begin{array}{l}\text { Surface charge and NP composition do not influence entry, NPs }<0.2 \mu \mathrm{m} \text { enter } \\
\text { RBCs, size is key factor for internalization by RBCs }\end{array}$} & \multirow[t]{3}{*}[76]{} \\
\hline $\mathrm{Au}$ & $25-1,000$ & & & & \\
\hline $\mathrm{TiO}_{2}$ & $20-30$ & & & & \\
\hline HAP & $14-175$ & $\mathrm{RBCs}$ & $\begin{array}{l}\text { Optical } \\
\text { microscopy, } \\
\text { TEM }\end{array}$ & $\begin{array}{l}\text { Surface charge more crucial than the size for NP-RBC interaction, NP adhesion } \\
\text { led to invaginations on RBC membrane }\end{array}$ & [80] \\
\hline $\mathrm{Au}$ & $4-5$ & DC2.4 & STM, CLSM & $\begin{array}{l}\text { 'Striped' NPs, decorated with alternating hydrophobic and hydrophilic ligands, } \\
\text { penetrate cell membranes without generating transient holes }\end{array}$ & [81] \\
\hline
\end{tabular}

Abbreviations used: SEIRAS surface-enhanced infrared absorption spectroscopy, HAP hydroxyapatite.

adsorbed to the surface of RBCs without disturbing the membrane or the cell morphology (Figure 3). In contrast, adsorption of large SBA-15-type MSNs ( 600 nm) induced strong local membrane deformations, followed by internalization of the particles and, eventually, hemolysis. The interactions of MSNs with the RBC membranes apparently depended on the presence of silanol groups on the particle surface because blocking these silanols with organic groups reduced their interactions with the RBC membranes.
Recently, Wang et al. [77] studied the interactions between 8-nm QDs coated with the small, zwitterionic amino acid ligand D-penicillamine (DPA) and RBCs. At neutral $\mathrm{pH}$, the charges on the amino and carboxylic acid groups of the surface ligands are balanced. After incubation with 10 nM DPA-QDs in PBS solution for different time periods and separation of free DPA-QDs by centrifugation, the $\mathrm{RBC}$ cells were transferred to a microscope sample cell and imaged using confocal fluorescence microscopy. The data clearly showed that the
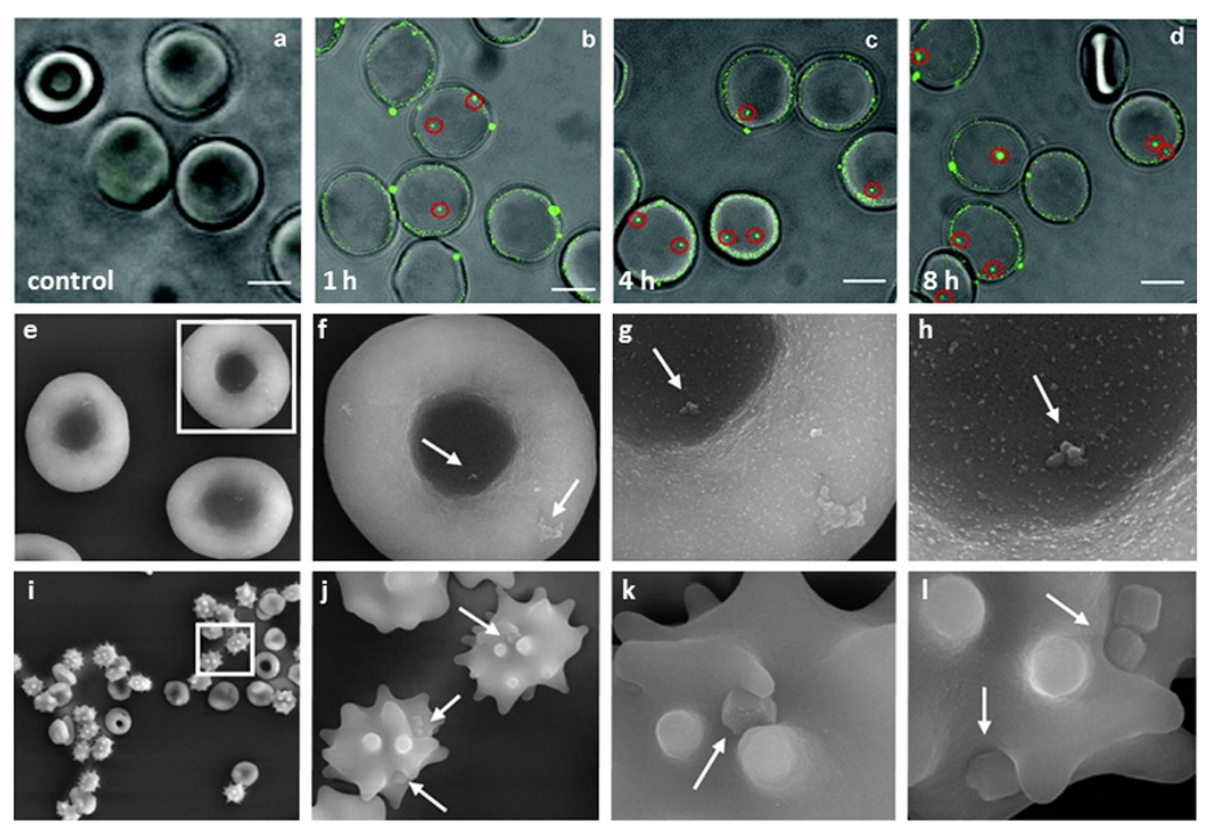

Figure 3 Passive NP uptake by red blood cells. (a - d) Internalization of DPA-QDs (8 nm) [77]. (e - I) Scanning electron micrographs (SEM) of RBCs (5\% hematocrit) incubated with $100 \mu \mathrm{g} \mathrm{mL}^{-1}$ of $(\mathbf{e}-\mathbf{h})$ small $(\sim 100 \mathrm{~nm})$ and $\mathbf{( i -} \mathbf{~ I ) ~ l a r g e ~}(\sim 600 \mathrm{~nm})$ mesoporous silica particles (MSN) [79]. Reproduced with permission from the American Chemical Society. 
DPA-QDs adhered to the RBC membranes, and the number of fluorescence spots, either close to the cell membranes or inside the cells, increased with exposure time (Figure 3). Moreover, the adsorbed DPA-QDs did not induce strong local membrane deformations. In fact, the RBC membranes remained largely intact during NP penetration of the bilayer, as evidenced by confocal microscopy images taken in the presence of calcein violet AM. This cell membrane-permeant dye becomes impermeant after entering the cell because of hydrolysis by intracellular esterases [81]. Surface-enhanced infrared absorption spectroscopy (SEIRAS) measurements carried out on model membrane preparations resembling $\mathrm{RBC}$ membranes revealed that the bilayer structure was softened in the presence of DPA-QDs, which may facilitate penetration of DPA-QDs into the lipid bilayer without causing poration.

The interaction of the NP with the membrane is arguably the most critical step in passive membrane penetration. Van Lehn et al. [82] proposed that, to avoid pore formation, the interaction should lead to fusion of the NP with the membrane. They suggested that fusion is highly favored when the ligand layer on the NP is able to easily fluctuate to adjust to the membrane, allowing surface charges to rearrange so that the NP appears locally hydrophobic. As the ligand layer around smaller particles contains a large amount of free volume because of the high curvature, ligand fluctuations are maximized so that small NPs should more easily penetrate a membrane. Certain small peptides [83,84] and synthetic nanomaterials such as carbon nanotubes [85] were found to be capable of crossing membranes without poration. The DPA monolayer of the QDs used by Wang et al. [77] resembles the pattern of hydrophobic and charged residues found in cell-penetrating peptides. Charged particles such as cationic QDs, however, typically induce transient poration of the cell membranes, which may result in cytotoxic effects [81].

\section{NP size affects cytotoxicity upon internalization}

A complete analysis of the pharmacokinetics of NPs has to include absorption of biomolecules, distribution, metabolism, and excretion [86]. A protein adsorption layer on the surface confers a new biological identity to the NP, which may completely modify the subsequent cellular and tissue responses, e.g., the distribution to various organs, tissues, and cells. Once inside a cell or tissue, the surface layer, including the adsorbed biomolecules, and also the NP core

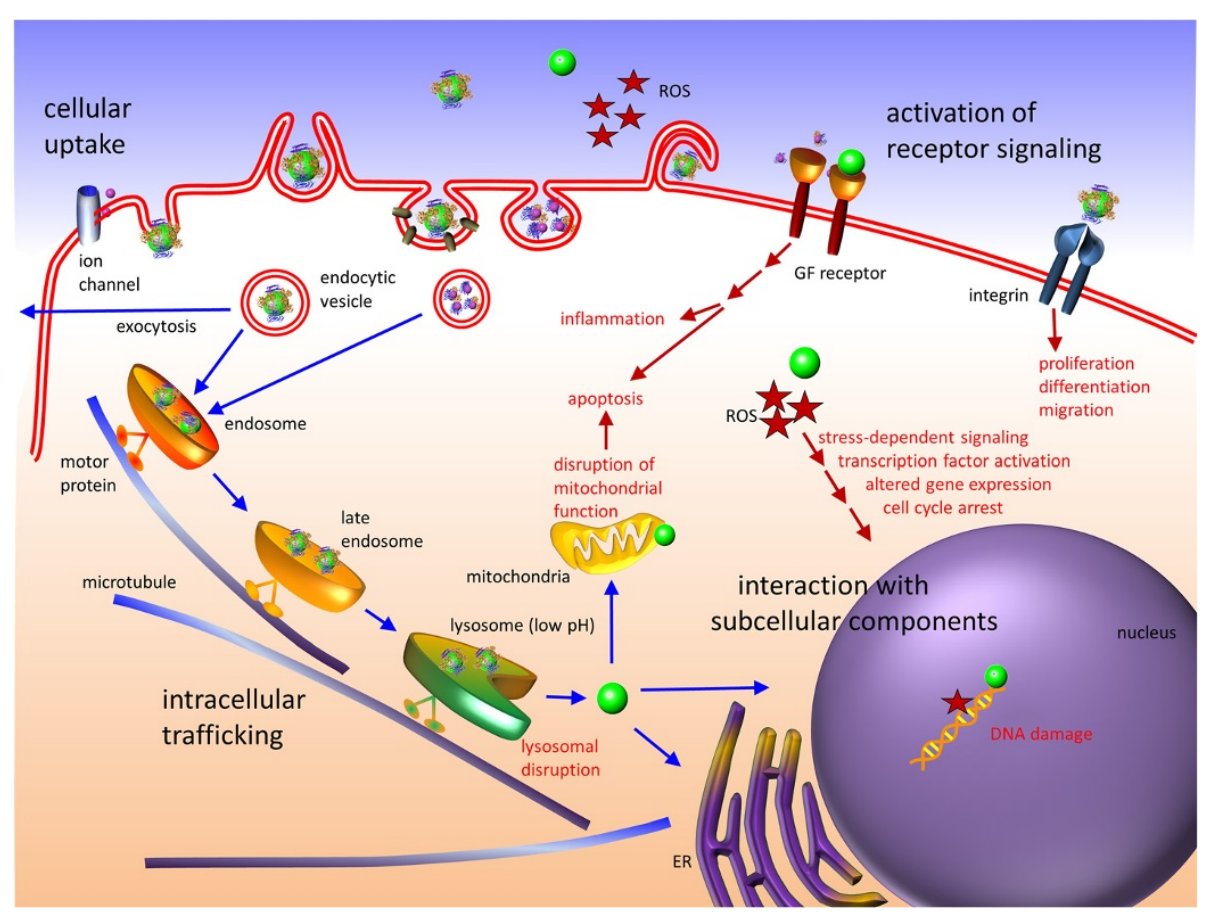

Figure 4 Cytotoxic effects of NPs. In the biological environment, NPs may trigger the production of reactive oxygen species (ROS). Elevated ROS levels may lead to (i) activation of cellular stress-dependent signaling pathways, (ii) direct damage of subcellular organelles such as mitochondria and (iii) DNA fragmentation in the nucleus, resulting in cell cycle arrest, apoptosis, and inflammatory response. NPs may interact with membrane-bound cellular receptors, e.g., growth factor (GF) receptors and integrins, inducing cellular phenotypes such as proliferation, apoptosis, differentiation, and migration. After internalization via endocytic pathways, NPs are trafficked along the endolysosomal network within vesicles with the help of motor proteins and cytoskeletal structures. To access cytoplasmic or nuclear targets, NPs must escape from the endolysosomal network and traverse through the crowded cytoplasm. 
material will likely be metabolized. Subsequently, the (remnants of the) NPs may be excreted by the organism. All these interactions with the biological environment are again dependent on the physicochemical properties of NPs including their size [87] (Figure 4). To evaluate the toxicity profile of NPs, two main approaches have been established: (i) functional assays assess the effects of NPs on cellular processes, (ii) viability assays probe whether the NPs cause death in a cell or a system of cells [88]. Although some aspects of size dependent NP toxicity may be reasonably well predicted by in vitro techniques, it remains difficult to judge whether the observed cytotoxicity is clinically relevant.

As can be inferred from the studies listed in Table 4, smaller NPs appear to be more toxic than larger ones. Small NPs possess a high surface area relative to their total mass, which increases the chance to interact with surrounding biomolecules and, as a consequence, to trigger adverse responses. Pan et al. [89] observed that small AuNPs $(1.4 \mathrm{~nm})$ were highly toxic and caused predominately rapid cell death by necrosis within $12 \mathrm{~h}$, while larger, 15-nm AuNPs displayed low toxicity, irrespective of cell type and surface ligands. Likewise, 4-nm AgNPs were found to induce much higher levels ROS production and interleukin-8 secretion than 20- and 70nm AgNPs at otherwise identical conditions [90]. A size dependent toxicity was also reported for $\mathrm{SiO}_{2}$ [91] and polymer NPs [92]. In contrast, the immunological responses of macrophages to AgNPs in the size range 3$25 \mathrm{~nm}$ were not significantly different, as inferred from the expression of the pro-inflammatory gene products interleukin-1, interleukin-6, and tumor necrosis factor [93]. Chen et al. [94] reported that Au NPs of 3, 5, 50, and $100 \mathrm{~nm}$ were nontoxic when injected intraperitoneally into mice, whereas Au NPs between 8 and $37 \mathrm{~nm}$ caused severe toxicity and death within 3 weeks. In HeLa cells, however, the same set of AuNPs was essentially non-toxic, regardless of size. The toxic effects in mice were less pronounced after coating the NP surface with peptides that induced an enhanced immune response. These apparently contradicting observations stress that caution is advised when it comes to drawing general conclusions on the in-vivo toxicity of a particular NP preparation from in-vitro data. In fact, the conditions under which nano-bio interactions take place in living organisms such as experimental mammals or humans are much more complex.

In summary, small NPs have a large, often catalytically active surface that may favor adverse chemical reactions such as ROS generation. Endocytosis mechanism, cellular uptake yield and efficiency of particle processing in the endocytic pathway also depend on the NP size [87]. In whole organisms, e.g., mice, the in-vivo NP toxicity is

Table 4 Size-dependent cytotoxicity of NPs

\begin{tabular}{|c|c|c|c|c|c|}
\hline NPs & $\begin{array}{l}\text { Size } \\
(\mathrm{nm}, \varnothing)\end{array}$ & Cell lines & Evaluation techniques & Main conclusions & Ref \\
\hline $\mathrm{Au}$ & $0.8-15$ & $\begin{array}{l}\text { SK-MEL-28, HeLa, } \\
\text { L929, J774A1 }\end{array}$ & TEM, MTT assays, FACS & $\begin{array}{l}\text { Cytotoxicity depends on size, not ligand } \\
\text { chemistry; small NPs more toxic }\end{array}$ & [89] \\
\hline QDs & $2.2,5.2$ & PC12, N9 & MTT assays & Smaller NPs more toxic & [72] \\
\hline $\mathrm{Au}$ & 5,15 & Balb/3 T3 & Colony forming efficiency, Trypan Blue assays & $5 \mathrm{~nm}$, toxic; $15 \mathrm{~nm}$, non-toxic & [95] \\
\hline $\mathrm{Au}$ & $3-38$ & $\mathrm{~J} 774 \mathrm{~A} 1$ & Sizing and counting of cells & \multirow{2}{*}{$\begin{array}{l}\text { AuNPs, increased toxicity for larger NPs; AgNPs, } \\
\text { no size-dependence in toxicity }\end{array}$} & \multirow[t]{2}{*}{ [93] } \\
\hline $\mathrm{Ag}$ & $3-25$ & & & & \\
\hline $\mathrm{Au}$ & $10-25$ & $\begin{array}{l}\text { HDMEC, A549, } \\
\text { NCIH441 }\end{array}$ & MTS assays, Ki-67 expression, LDH release & $\begin{array}{l}\text { Size not a significant factor for cytotoxicity } \\
\text { compared with surface ligands }\end{array}$ & [96] \\
\hline $\mathrm{Ag}$ & $15-55$ & $\mathrm{~F}-12 \mathrm{~K}$ & $\begin{array}{l}\text { MTT assays, LDH leakage, ROS production, MMP, } \\
\text { inflammatory response }\end{array}$ & Increased toxicity for smaller NPs & [97] \\
\hline $\mathrm{Ag}$ & $4-70$ & U937 & Cell viability, ROS production, cytokine release assays & Size-dependent toxicity (4 nm highest) & [90] \\
\hline $\mathrm{SiO}_{2}$ & 32,83 & Caco-2 & WST- 1 assays, comet assays & No cytotoxicity detected for either size & [55] \\
\hline polymer & 45,90 & NR8383, Caco-2 & $\begin{array}{l}\text { Mitochondrial membrane potential, ROS production, } \\
\text { ATP depletion, TNF-a release }\end{array}$ & $\begin{array}{l}\text { Positively charged } 45-\mathrm{nm} \text { NPs more toxic than } \\
\text { equally charged } 90-\mathrm{nm} \text { NPs }\end{array}$ & [92] \\
\hline $\mathrm{Ag}$ & $10-100$ & МС3Т3, PC12 & $\begin{array}{l}\text { Cell viability, ROS production, } \mathrm{LDH} \text { release assays, } \\
\text { gene expression, apoptosis detection }\end{array}$ & $10 \mathrm{~nm}$ : greatest amount of apoptosis & [98] \\
\hline $\mathrm{TiO}_{2}$ & $14-196$ & $\begin{array}{l}\text { Osteoblasts, L-02, } \\
\text { HEK } 293\end{array}$ & Alkaline phosphatase and zymography evaluation & Size-dependent cytotoxicity, 100 nm critical size & [99] \\
\hline $\mathrm{Au}$ & 20,200 & DU-145 & MTS assays & Both sizes cytotoxic & [100] \\
\hline $\mathrm{SiO}_{2}$ & 50,200 & GT1-7 & Counting cells, intracellular calcium homeostasis & $\begin{array}{l}200 \mathrm{~nm} \text { : no toxic effects, } 50 \mathrm{~nm} \text { : toxicity with } \\
\text { Ca level increase }\end{array}$ & [91] \\
\hline
\end{tabular}

Abbreviations used: MTT 3-(4,5-dimethylthiazol-2-yl)-2,5-diphenyltetrazolium bromide, FACS fluorescence-activated cell sorting, LDH lactate dehydrogenase, MTS (3(4,5-dimethylthiazol-2-yl)-5-(3-carboxymethoxyphenyl)-2-(4-sulfophenyl)-2H-tetrazolium) tetrazolium, ROS Reactive Oxygen Species, MMP mitochondrial membrane potential, WST water-soluble tetrazolium salt. 
directly related to the biodistribution and the retention times, which are both size-dependent. Overall, the harmfulness of NPs may closely correlate with their size-related ability to readily enter biological systems. However, size is not the only factor that governs toxicity; other factors such as surface functionalization also play important roles. For example, cationic NPs are considered more toxic than neutral or anionic ones, possibly due to their high affinity towards the negatively charged plasma membrane. Therefore, NP toxicity must be evaluated by changing NP properties systematically, one at a time.

\section{Conclusions}

In summary, the size of NPs has a strong effect on their interactions with living cells, influencing uptake efficiency, internalization pathway selection, intracellular localization and cytotoxicity. Despite huge efforts in this area, it still remains challenging to reliably correlate a particular cellular response with NP size. Considering the vast variety of nanomaterials and the complexity of the biological probes, it is difficult to draw general conclusions from the huge pool of available data. Still, we believe that there are a few general trends that can be trusted. (i) There is an optimal size for efficient endocytosis of NPs independent of the particle composition. (ii) This critical size can vary with cell type and surface properties of the NPs. (iii) Small NPs have a higher probability to be internalized by passive uptake than large ones. (iv) Under otherwise identical conditions, small NPs are more likely to cause toxic cellular responses.

Further research on NP-cell interactions will benefit from advances in the synthesis of well-defined, monodisperse NPs and the development of sophisticated analysis tools. We are confident that these efforts will result in a better understanding of the influence of physicochemical properties of nanomaterials on their interaction with biological systems and will provide guidelines to the design of more advanced biocompatible and efficient nanodevices.

\section{Competing interests}

The authors declare that they have no competing interests.

\section{Authors' contributions}

All authors have written and approved the final manuscript. They agree to be accountable for all aspects of the work in ensuring that questions related to the accuracy or integrity of any part of the work are appropriately investigated and resolved.

\section{Acknowledgements}

Financial support from the Deutsche Forschungsgemeinschaft (DFG) through the Center for Functional Nanostructures (CFN) and the Priority Program SPP1313 is gratefully acknowledged.

\section{Author details}

'Institute of Applied Physics and Center for Functional Nanostructures (CFN), Karlsruhe Institute of Technology (KIT), Wolfgang-Gaede-Strasse 1, 76131 Karlsruhe, Germany. ${ }^{2}$ Institute of Toxicology and Genetics (ITG), Karlsruhe Institute of Technology (KIT), Hermann-von-Helmholtz-Platz 1, 76344 Eggenstein-Leopoldshafen, Germany. ${ }^{3}$ Department of Physics, University of Illinois at Urbana-Champaign, Urbana, IL 61801, USA.

Received: 3 January 2014 Accepted: 31 January 2014

Published: 3 February 2014

\section{References}

1. Astruc D: Transition - metal nanoparticles in catalysis: from historical background to the state - of - the art. In Nanoparticles and Catalysis. Edited by Astruc D. KGaA, Weinheim: WILEY-VCH Verlag GmbH \& Co; 2008.

2. Saha K, Agasti SS, Kim C, Li XN, Rotello VM: Gold nanoparticles in chemical and biological sensing. Chem Rev 2012, 112:2739-2779.

3. Stratakis E, Kymakis E: Nanoparticle-based plasmonic organic photovoltaic devices. Mater Today 2013, 16:133-146.

4. Saroja C, Lakshmi P, Bhaskaran S: Recent trends in vaccine delivery systems: a review. Int J Pharm Invest 2011, 1:64-74.

5. Meng FH, Cheng R, Deng C, Zhong ZY: Intracellular drug release nanosystems. Mater Today 2012, 15:436-442.

6. Yoo JW, Irvine DJ, Discher DE, Mitragotri S: Bio-inspired, bioengineered and biomimetic drug delivery carriers. Nat Rev Drug Discov 2011, 10:521-535.

7. Stark WJ: Nanoparticles in biological systems. Angew Chem Int Ed 2011, 50:1242-1258.

8. Cheng LC, Jiang XM, Wang J, Chen CY, Liu RS: Nano-bio effects: interaction of nanomaterials with cells. Nanoscale 2013, 5:3547-3569.

9. Röcker C, Pötzl M, Zhang F, Parak WJ, Nienhaus GU: A quantitative fluorescence study of protein monolayer formation on colloidal nanoparticles. Nat Nanotechnol 2009, 4:577-580.

10. Jiang X, Weise S, Hafner M, Röcker C, Zhang F, Parak WJ, Nienhaus GU: Quantitative analysis of the protein corona on FePt nanoparticles formed by transferrin binding. J R Soc Interface 2010, 7(Suppl 1):S5-S13.

11. Maffre P, Nienhaus K, Amin F, Parak WJ, Nienhaus GU: Characterization of protein adsorption onto FePt nanoparticles using dual-focus fluorescence correlation spectroscopy. Beilstein I Nanotechnol 2011, 2:374-383.

12. Lynch I, Salvati A, Dawson KA: Protein-nanoparticle interactions: what does the cell see? Nat Nanotechnol 2009, 4:546-547.

13. Lundqvist M, Stigler J, Cedervall T, Berggard T, Flanagan MB, Lynch I, Elia G, Dawson $\mathrm{K}$ : The evolution of the protein corona around nanoparticles: a test study. ACS Nano 2011, 5:7503-7509.

14. Verma A, Stellacci F: Effect of surface properties on nanoparticle-cell interactions. Small 2010, 6:12-21.

15. Mahmoudi M, Saeedi-Eslami SN, Shokrgozar MA, Azadmanesh K, Hassanlou M, Kalhor HR, Burtea C, Rothen-Rutishauser B, Laurent S, Sheibani S, Vali H: Cell "vision": complementary factor of protein corona in nanotoxicology. Nanoscale 2012, 4:5461-5468.

16. Cho EC, Zhang Q, Xia Y: The effect of sedimentation and diffusion on cellular uptake of gold nanoparticles. Nat Nanotechnol 2011, 6:385-391.

17. Li LW, Mu QX, Zhang B, Yan B: Analytical strategies for detecting nanoparticle-protein interactions. Analyst 2010, 135:1519-1530.

18. Saptarshi S, Duschl A, Lopata A: Interaction of nanoparticles with proteins: relation to bio-reactivity of the nanoparticle. J Nanobiotechnol 2013, 11:26.

19. Mahl D, Diendorf J, Meyer-Zaika W, Epple M: Possibilities and limitations of different analytical methods for the size determination of a bimodal dispersion of metallic nanoparticles. Colloids Surf A 2011, 377:386-392.

20. Cho EJ, Holback H, Liu KC, Abouelmagd SA, Park J, Yeo Y: Nanoparticle characterization: state of the art, challenges, and emerging technologies. Mol Pharm 2013, 10:2093-2110.

21. Zemanova L, Schenk A, Nienhaus GU, Valler MJ, Heilker R: Confocal optics microscopy for biochemical and cellular high-throughput screening. Drug Discov Today 2004, 9:26-26.

22. Nienhaus GU, Maffre P, Nienhaus K: Studying the protein corona on nanoparticles by FCS. Methods Enzymol 2013, 519:115-137.

23. Saveyn H, De Baets B, Thas O, Hole P, Smith J, Van der Meeren P: Accurate particle size distribution determination by nanoparticle tracking analysis based on 2-D Brownian dynamics simulation. J Colloid Interf Sci 2010, 352:593-600. 
24. Glatzel T, Hölscher H, Schimmel T, Baykara MZ, Schwarz UD, Garcia R: Advanced atomic force microscopy techniques. Beilstein J Nanotechnol 2012, 3:893-894

25. Haiss W, Thanh NTK, Aveyard J, Fernig DG: Determination of size and concentration of gold nanoparticles from UV-vis spectra. Anal Chem 2007, 79:4215-4221.

26. Planken $\mathrm{KL}$, Colfen $\mathrm{H}$ : Analytical ultracentrifugation of colloids. Nanoscale 2010, 2:1849-1869.

27. Hoo C, Starostin N, West P, Mecartney M: A comparison of atomic force microscopy (AFM) and dynamic light scattering (DLS) methods to characterize nanoparticle size distributions. J Nanopart Res 2008, 10:89-96.

28. MacCuspie R: Colloidal stability of silver nanoparticles in biologically relevant conditions. J Nanopart Res 2011, 13:2893-2908.

29. Malugin A, Ghandehari $\mathrm{H}$ : Cellular uptake and toxicity of gold nanoparticles in prostate cancer cells: a comparative study of rods and spheres. J Appl Toxicol 2010, 30:212-217.

30. Treuel L, Nienhaus G: Toward a molecular understanding of nanoparticleprotein interactions. Biophys Rev 2012, 4:137-147.

31. Monopoli MP, Walczyk D, Campbell A, Elia G, Lynch I, Baldelli Bombelli F, Dawson KA: Physical-chemical aspects of protein corona: relevance to in vitro and in vivo biological impacts of nanoparticles. J Am Chem Soc 2011, 133:2525-2534.

32. Shang L, Dörlich RM, Trouillet V, Bruns M, Nienhaus GU: Ultrasmall fluorescent silver nanoclusters: protein adsorption and its effects on cellular responses. Nano Res 2012, 5:531-542.

33. Wang J, Jensen UB, Jensen GV, Shipovskov S, Balakrishnan VS, Otzen D, Pedersen JS, Besenbacher F, Sutherland DS: Soft interactions at nanoparticles alter protein function and conformation in a size dependent manner. Nano Lett 2011, 11:4985-4991.

34. Tenzer S, Docter D, Rosfa S, Wlodarski A, Kuharev J, Rekik A, Knauer SK, Bantz C, Nawroth T, Bier C, et al: Nanoparticle size is a critical physicochemical determinant of the human blood plasma corona: a comprehensive quantitative proteomic analysis. ACS Nano 2011, 5:7155-7167.

35. Shang W, Nuffer JH, Muniz-Papandrea VA, Colon W, Siegel RW, Dordick JS: Cytochrome c on silica nanoparticles: influence of nanoparticle size on protein structure, stability, and activity. Small 2009, 5:470-476.

36. Tenzer S, Docter D, Kuharev J, Musyanovych A, Fetz V, Hecht R, Schlenk F, Fischer D, Kiouptsi K, Reinhardt C, et al: Rapid formation of plasma protein corona critically affects nanoparticle pathophysiology. Nat Nanotechnol 2013, 8:772-781

37. Iversen TG, Skotland T, Sandvig K: Endocytosis and intracellular transport of nanoparticles: present knowledge and need for future studies. Nano Today 2011, 6:176-185.

38. Canton I, Battaglia G: Endocytosis at the nanoscale. Chem Soc Rev 2012, 41:2718-2739

39. Chithrani BD, Ghazani AA, Chan WCW: Determining the size and shape dependence of gold nanoparticle uptake into mammalian cells. Nano Lett 2006, 6:662-668.

40. Wang SH, Lee CW, Chiou A, Wei PK: Size-dependent endocytosis of gold nanoparticles studied by three-dimensional mapping of plasmonic scattering images. J Nanobiotechnol 2010, 8:33.

41. Lu F, Wu SH, Hung Y, Mou CY: Size effect on cell uptake in wellsuspended, uniform mesoporous silica nanoparticles. Small 2009, 5:1408-1413.

42. Varela JA, Bexiga MG, Aberg C, Simpson JC, Dawson KA: Quantifying sizedependent interactions between fluorescently labeled polystyrene nanoparticles and mammalian cells. J Nanobiotechnol 2012, 10:39.

43. Huang J, Bu L, Xie J, Chen K, Cheng Z, Li X, Chen X: Effects of nanoparticle size on cellular uptake and liver MRI with polyvinylpyrrolidone-coated iron oxide nanoparticles. ACS Nano 2010, 4:7151-7160.

44. Huang K, Ma H, Liu J, Huo S, Kumar A, Wei T, Zhang X, Jin S, Gan Y, Wang $P C$, et al: Size-dependent localization and penetration of ultrasmall gold nanoparticles in cancer cells, multicellular spheroids, and tumors in vivo. ACS Nano 2012, 6:4483-4493

45. Dong C, Irudayaraj J: Hydrodynamic size-dependent cellular uptake of aqueous QDs probed by fluorescence correlation spectroscopy. J Phys Chem B 2012, 116:12125-12132.

46. Oh E, Delehanty JB, Sapsford KE, Susumu K, Goswami R, Blanco-Canosa JB, Dawson PE, Granek J, Shoff M, Zhang Q, et al: Cellular uptake and fate of
PEGylated gold nanoparticles is dependent on both cell-penetration peptides and particle size. ACS Nano 2011, 5:6434-6448.

47. Jiang W, Kim BYS, Rutka JT, Chan WCW: Nanoparticle-mediated cellular response is size-dependent. Nat Nanotechnol 2008, 3:145-150.

48. Shan Y, Ma S, Nie L, Shang X, Hao X, Tang Z, Wang H: Size-dependent endocytosis of single gold nanoparticles. Chem Commun 2011, 47:8091-8093.

49. Andersson PO, Lejon C, Ekstrand-Hammarstrom B, Akfur C, Ahlinder L, Bucht A, Osterlund L: Polymorph- and size-dependent uptake and toxicity of TiO(2) nanoparticles in living lung epithelial cells. Small 2011, 7:514-523.

50. Mironava T, Hadjiargyrou M, Simon M, Jurukovski V, Rafailovich MH: Gold nanoparticles cellular toxicity and recovery: effect of size, concentration and exposure time. Nanotoxicology 2010, 4:120-137.

51. Cho EC, Au L, Zhang Q, Xia Y: The effects of size, shape, and surface functional group of gold nanostructures on their adsorption and internalization by cells. Small 2010, 6:517-522.

52. Walkey CD, Olsen JB, Guo H, Emili A, Chan WC: Nanoparticle size and surface chemistry determine serum protein adsorption and macrophage uptake. J Am Chem Soc 2012, 134:2139-2147.

53. Liu X, Huang N, Li H, Jin Q, Ji J: Surface and size effects on cell interaction of gold nanoparticles with both phagocytic and nonphagocytic cells. Langmuir 2013, 29:9138-9148.

54. Elbakry A, Wurster EC, Zaky A, Liebl R, Schindler E, Bauer-Kreisel P, Blunk T, Rachel R, Goepferich A, Breunig M: Layer-by-layer coated gold nanoparticles: size-dependent delivery of DNA into cells. Small 2012, 8:3847-3856.

55. Schübbe S, Schumann C, Cavelius C, Koch M, Müller T, Kraegeloh A: Sizedependent localization and quantitative evaluation of the intracellular migration of silica nanoparticles in caco-2 cells. Chem Mater 2012, 24:914-923.

56. dos Santos T, Varela J, Lynch I, Salvati A, Dawson KA: Quantitative assessment of the comparative nanoparticle-uptake efficiency of a range of cell lines. Small 2011, 7:3341-3349.

57. Xu A, Yao M, Xu G, Ying J, Ma W, Li B, Jin Y: A physical model for the sizedependent cellular uptake of nanoparticles modified with cationic surfactants. Int J Nanomedicine 2012, 7:3547-3554.

58. He C, Hu Y, Yin L, Tang C, Yin C: Effects of particle size and surface charge on cellular uptake and biodistribution of polymeric nanoparticles. Biomaterials 2010, 31:3657-3666.

59. Rejman J, Oberle V, Zuhorn IS, Hoekstra D: Size-dependent internalization of particles via the pathways of clathrin- and caveolae-mediated endocytosis. Biochem J 2004, 377:159-169.

60. Jiang X, Röcker C, Hafner M, Brandholt S, Dörlich RM, Nienhaus GU: Endoand exocytosis of zwitterionic quantum dot nanoparticles by live HeLa cells. ACS Nano 2010, 4:6787-6797.

61. Yang L, Shang L, Nienhaus GU: Mechanistic aspects of fluorescent gold nanocluster internalization by live HeLa cells. Nanoscale 2013, 5:1537-1543.

62. Shang L, Stockmar F, Azadfar N, Nienhaus GU: Intracellular thermometry by using fluorescent gold nanoclusters. Angew Chem Int Ed Engl 2013, 52:11154-11157.

63. Jiang X, Dausend J, Hafner M, Musyanovych A, Röcker C, Landfester K, Mailänder V, Nienhaus GU: Specific effects of surface amines on polystyrene nanoparticles in their interactions with mesenchymal stem cells. Biomacromolecules 2010, 11:748-753.

64. Jiang X, Musyanovych A, Röcker C, Landfester K, Mailänder V, Nienhaus GU: Specific effects of surface carboxyl groups on anionic polystyrene particles in their interactions with mesenchymal stem cells. Nanoscale 2011, 3:2028-2035.

65. Lunov O, Syrovets T, Loos C, Beil J, Delacher M, Tron K, Nienhaus GU, Musyanovych A, Mailänder V, Landfester K, Simmet T: Differential uptake of functionalized polystyrene nanoparticles by human macrophages and a monocytic cell line. ACS Nano 2011, 5:1657-1669.

66. Lunov O, Syrovets T, Loos C, Nienhaus GU, Mailänder V, Landfester K, Rouis $\mathrm{M}$, Simmet T: Amino-functionalized polystyrene nanoparticles activate the NLRP3 inflammasome in human macrophages. ACS Nano 2011, 5:9648-9657.

67. Hühn D, Kantner K, Geidel C, Brandholt S, De Cock I, Soenen SJ, Rivera Gil P, Montenegro JM, Braeckmans K, Mullen K, et al: Polymer-coated nanoparticles interacting with proteins and cells: focusing on the sign of the net charge. ACS Nano 2013, 7:3253-3263.

68. Albanese A, Tang PS, Chan WC: The effect of nanoparticle size, shape, and surface chemistry on biological systems. Annu Rev Biomed Eng 2012, $14: 1-16$. 
69. Lunov O, Zablotskii V, Syrovets T, Röcker C, Tron K, Nienhaus GU, Simmet T: Modeling receptor-mediated endocytosis of polymer-functionalized iron oxide nanoparticles by human macrophages. Biomaterials 2011, 32:547-555.

70. Yuan H, Li J, Bao G, Zhang S: Variable nanoparticle-cell adhesion strength regulates cellular uptake. Phys Rev Lett 2010, 105:138101.

71. Shang L, Yang L, Seiter J, Heinle M, Brenner-Weiss G, Gerthsen D, Nienhaus GU: Nanoparticles interacting with proteins and cells: a systematic study of protein surface charge effects. Adv Mater Interfaces 2014. 10.1002/ admi.201300079.

72. Lovrić J, Bazzi H, Cuie Y, Fortin GA, Winnik F, Maysinger D: Differences in subcellular distribution and toxicity of green and red emitting CdTe quantum dots. J Mol Med 2005, 83:377-385.

73. Parak WJ, Boudreau R, Le Gros MA, Gerion D, Zanchet D, Micheel CM, Williams SC, Alivisatos AP, Larabell C: Cell motility and metastatic potential studies based on quantum dot imaging of phagokinetic tracks. Adv Mater 2002, 14:882-885.

74. Underhill DM, Ozinsky A: Phagocytosis of microbes: complexity in action. Annu Rev Immunol 2002, 20:825-852.

75. Geiser M, Rothen-Rutishauser B, Kapp N, Schurch S, Kreyling W, Schulz H, Semmler M, Im Hof V, Heyder J, Gehr P: Ultrafine particles cross cellula membranes by nonphagocytic mechanisms in lungs and in cultured cells. Environ Health Perspect 2005, 113:1555-1560.

76. Rothen-Rutishauser BM, Schurch S, Haenni B, Kapp N, Gehr P: Interaction of fine particles and nanoparticles with red blood cells visualized with advanced microscopic techniques. Environ Sci Technol 2006, 40:4353-4359.

77. Wang T, Bai J, Jiang X, Nienhaus GU: Cellular uptake of nanoparticles by membrane penetration: a study combining confocal microscopy with FTIR spectroelectrochemistry. ACS Nano 2012, 6:1251-1259.

78. Slowing II, Wu CW, Vivero-Escoto JL, Lin VS: Mesoporous silica nanoparticles for reducing hemolytic activity towards mammalian red blood cells. Small 2009, 5:57-62.

79. Zhao Y, Sun X, Zhang G, Trewyn BG, Slowing II, Lin VS: Interaction of mesoporous silica nanoparticles with human red blood cell membranes: size and surface effects. ACS Nano 2011, 5:1366-1375.

80. Han Y, Wang X, Dai H, Li S: Nanosize and surface charge effects of hydroxyapatite nanoparticles on Red blood cell suspensions. ACS Appl Mater Interfaces 2012, 4:4616-4622.

81. Verma A, Uzun O, Hu Y, Han HS, Watson N, Chen S, Irvine DJ, Stellacci F: Surface-structure-regulated cell-membrane penetration by monolayerprotected nanoparticles. Nat Mater 2008, 7:588-595.

82. Van Lehn RC, Atukorale PU, Carney RP, Yang YS, Stellacci F, Irvine DJ, Alexander-Katz A: Effect of particle diameter and surface composition on the spontaneous fusion of monolayer-protected gold nanoparticles with lipid bilayers. Nano Lett 2013, 13:4060-4067.

83. Koren E, Torchilin VP: Cell-penetrating peptides: breaking through to the other side. Trends Mol Med 2012, 18:385-393.

84. Heitz F, Morris MC, Divita G: Twenty years of cell-penetrating peptides: from molecular mechanisms to therapeutics. Br J Pharmacol 2009, 157:195-206.

85. Kostarelos K, Lacerda L, Pastorin G, Wu W, Wieckowski S, Luangsivilay J, Godefroy S, Pantarotto D, Briand JP, Muller S, et al: Cellular uptake of functionalized carbon nanotubes is independent of functional group and cell type. Nat Nanotechnol 2007, 2:108-113.

86. Sharifi S, Behzadi S, Laurent S, Forrest ML, Stroeve P, Mahmoudi M: Toxicity of nanomaterials. Chem Soc Rev 2012, 41:2323-2343.

87. Nel A, Xia T, Madler L, Li N: Toxic potential of materials at the nanolevel. science 2006, 311:622-627.

88. Love SA, Maurer-Jones MA, Thompson JW, Lin Y-S, Haynes CL: Assessing nanoparticle toxicity. Annu Rev Anal Chem 2012, 5:181-205.

89. Pan Y, Neuss S, Leifert A, Fischler M, Wen F, Simon U, Schmid G, Brandau W, Jahnen-Dechent W: Size-dependent cytotoxicity of gold nanoparticles. Small 2007, 3:1941-1949.

90. Park J, Lim DH, Lim HJ, Kwon T, Choi JS, Jeong S, Choi IH, Cheon J: Size dependent macrophage responses and toxicological effects of $\mathrm{Ag}$ nanoparticles. Chem Commun 2011, 47:4382-4384.

91. Ariano P, Zamburlin P, Gilardino A, Mortera R, Onida B, Tomatis M, Ghiazza M, Fubini B, Lovisolo D: Interaction of spherical silica nanoparticles with neuronal cells: size-dependent toxicity and perturbation of calcium homeostasis. Small 2011, 7:766-774.
92. Bhattacharjee S, Ershov D, Fytianos K, van der Gucht J, Alink GM, Rietjens IMCM, Marcelis ATM, Zuilhof H: Cytotoxicity and cellular uptake of triblock copolymer nanoparticles with different size and surface characteristics. Part Fibre Toxicol 2012, 9:11

93. Yen HJ, Hsu SH, Tsai CL: Cytotoxicity and immunological response of gold and silver nanoparticles of different sizes. Small 2009, 5:1553-1561.

94. Chen YS, Hung YC, Liau I, Huang GS: Assessment of the in vivo toxicity of gold nanoparticles. Nanoscale Res Lett 2009, 4:858-864.

95. Coradeghini R, Gioria S, Garcia CP, Nativo P, Franchini F, Gilliland D, Ponti J, Rossi F: Size-dependent toxicity and cell interaction mechanisms of gold nanoparticles on mouse fibroblasts. Toxicol Lett 2013, 217:205-216.

96. Freese C, Uboldi C, Gibson MI, Unger RE, Weksler BB, Romero IA, Couraud PO, Kirkpatrick CJ: Uptake and cytotoxicity of citrate-coated gold nanospheres: Comparative studies on human endothelial and epithelial cells. Part Fibre Toxicol 2012, 9:23

97. Carlson C, Hussain SM, Schrand AM K, Braydich-Stolle L, Hess KL, Jones RL, Schlager JJ: Unique cellular interaction of silver nanoparticles: sizedependent generation of reactive oxygen species. J Phys Chem B 2008, 112:13608-13619.

98. Kim T-H, Kim M, Park H-S, Shin US, Gong M-S, Kim H-W: Size-dependent cellular toxicity of silver nanoparticles. J Biomed Mater Res A 2012, 100A:1033-1043.

99. Cai K, Hou Y, Hu Y, Zhao L, Luo Z, Shi Y, Lai M, Yang W, Liu P: Correlation of the cytotoxicity of $\mathrm{TiO}_{2}$ nanoparticles with different particle sizes on a sub-200-nm scale. Small 2011, 7:3026-3031.

100. Vedantam P, Huang G, Tzeng TRJ: Size-dependent cellular toxicity and uptake of commercial colloidal gold nanoparticles in DU-145 cells. Cancer Nanotechnol 2013, 4:13-20.

doi:10.1186/1477-3155-12-5

Cite this article as: Shang et al:: Engineered nanoparticles interacting with cells: size matters. Journal of Nanobiotechnology 2014 12:5.

\section{Submit your next manuscript to BioMed Central and take full advantage of:}

- Convenient online submission

- Thorough peer review

- No space constraints or color figure charges

- Immediate publication on acceptance

- Inclusion in PubMed, CAS, Scopus and Google Scholar

- Research which is freely available for redistribution 